\title{
DETERMINATION OF TOTAL CONTENTS OF FLUID INCLUSIONS IN QUARTZ USING MODAL ANALYSIS: EXAMPLES FROM PROTEROZOIC ROCKS AND ORE DEPOSITS IN FINLAND
}

\author{
KARI A. KINNUNEN
}

\begin{abstract}
KINNUNEN, KARI A., 1989. Determination of total contents of fluid inclusions in quartz using modal analysis: Examples from Proterozoic rocks and ore deposits in Finland. Bull. Geol. Soc. Finland 61, Part 2, 197-208.

A modified linear measurement procedure following Rosiwal's method to determine the total volume contents of fluid inclusions in minerals is described. The contents were determined from quartz crystals and grains in 13 Proterozoic rock and ore specimens from Finland. The quartz contained primary, pseudo-secondary and secondary fluid inclusions with five main filling types identified with optical methods, a crushing stage and heating/freezing runs. In hydrothermal quartz crystals (smoky quartz) the fluid inclusion contents were high, from 1.070 to $1.661 \mathrm{vol}$ ume percent, whereas in metamorphic and magmatic quartz and in quartz veins the total contents ranged from 0.028 to 0.917 volume per cent. A high positive linear correlation, $r=0.915$, exists between the average intercept length and total contents of inclusions in the quartz specimens studied. The mean intercept lengths of fluid inclusions in metamorphic and magmatic rock-forming quartz were exceedingly small, ranging from the limit of resolution of the optical system used up to 3.13 microns. Practical applications of the determinations of fluid inclusion contents to the purity evaluation of mineral raw materials, to the estimation of the polishing properties of the smoky quartz used as gem material and to fluid-rock interactions in connection with nuclear waste site studies in crystalline bedrock are briefly discussed.
\end{abstract}

Key words: fluid inclusions, volume, quartz, modal analysis, rocks, metal ores, Proterozoic, Finland.

Kari A. Kinnunen: Geological Survey of Finland. SF-02150 Espoo, Finland.

\section{Introduction}

Fluid inclusions, gaseous and liquid impurities common in many terrestrial minerals, are microscopic remnants of the omnipresent fluid phase characterizing the past and present Earth's crust. Most fluids in the inclusions represent the C-O-H-S(-N) system with water-soluble salts (Holloway 1981). It is noteworthy that almost all the extraterrestrial minerals in chondritic meteorites and lunar rocks studied so far (Roedder 1984) lack confirmed fluid inclusions.

In recent years, interest in fluid inclusions has been triggered by the search for ultra-pure mineral raw materials, e.g. quartz, for the glass and high-technology electronics industry (Saikkonen 1981); by site investigations for the final underground disposal of high-level nuclear waste with special reference to the deep saline ground waters chemically balanced due to fluid-rock interac- 
tions (Hyyppä 1963; Kankainen 1982; Hyyppä 1986; Nurmi et al. 1988); and by the estimation of polishability, mainly undercutting, hampered by exposed inclusion cavities, of the smoky quartz used for cabochon material. These problems, together with the petrological study of fluid inclusions in metamorphic rocks with their implications for the generation of retrograde metamorphic fluids (see Spear and Selverstone 1983), require at least some knowledge of the actual volume content of fluid inclusions as chemical impurities in specific raw materials and in the crystalline bedrock. Conventional fluid inclusion studies, which mainly deal with the genesis of ore deposits, have centred on the thermometrical parameters of inclusions indicative of the PTX conditions of the mineralizing fluid. Therefore, the volume content of inclusions has been neglected, mainly because of the considerable difficulty of determining it reliably, but also because it has not been assumed to have any direct significance for the interpretation of ore genesis.

\section{Analysis methods}

Thus, little is known about the actual volume content of fluid inclusions in minerals, although a few procedures have been proposed for estimating this parameter (e.g., Lindblom 1984). Roedder (1984, Fig. 5-1) prepared a nomograph depicting the variation in the density of quartz calculated from the volume percentage of inclusions in quartz. Shatagin (1981) outlined a mathematical method based on the geometrical probabilities of the closest neighbour (in this case inclusion) to evaluate the amount of inclusions in minerals. Yermakov and Myaz' (1965) studied the influence of fluid inclusions on the magnitude of losses on ignition of minerals, mainly quartz, up to $1200^{\circ} \mathrm{C}$. Ventslovayte and Valyashko (1985) determined the water content of quartz with gas chromatography using decrepitation in a $320^{\circ}-500^{\circ} \mathrm{C}$ temperature range.

These procedures were impractical or inaccurate for determining the actual volume content of fluid inclusions in minerals. First, the smallest fluid inclusions do not usually decrepitate at the temperature used by Ventslovayte and Valyashko (1985), not even when markedly overheated above their filling temperatures, as by Yermakov and Myaz' (1965). Consequently, the losses on ignition do not give accurate results. Second, as the density of quartz depends on the presence of mineral inclusions, very small fragments, even though microscopically clean, do not indicate reliably the fluid inclusion contents if measured from density. The pycnometer method used for density determination requires fine-grained samples, but grinding inevitably destroys large fluid inclusions. Third, the geometrical method proposed by Shatagin (1981) gives only a very crude estimate of the number of inclusions per unit area, and because inclusions vary widely in size, it is practically impossible to translate these values into true volume contents. For these reasons, the routine modal analysis (Chays 1956) was modified to meet the requirements of the measurement of line intercept lengths inside individual mineral grains according to the Rosiwal's method (see Jones 1987).

Table 1. The observed host minerals of fluid inclusions in Finnish rocks and ore deposits studied by the author. The minerals containing S5 inclusions exclusively were omitted. Inclusion types: $\mathrm{P}=$ primary and secondary fluid inclusions; $\mathrm{S}=$ generally only secondary fluid inclusions. The minerals are listed in descending order of importance for fluid inclusion studies in each column.

\begin{tabular}{|c|c|c|c|c|c|}
\hline $\begin{array}{l}\text { Common } \\
\text { as host }\end{array}$ & types & $\begin{array}{l}\text { Occasionally } \\
\text { as host }\end{array}$ & types & $\begin{array}{l}\text { Very rare } \\
\text { as host }\end{array}$ & types \\
\hline Quartz & $\mathrm{P}$ & Pyroxenes & $\mathbf{P}$ & Sphalerite & S \\
\hline Carbonates & $\mathrm{P}$ & Apatite & $\mathbf{P}$ & Scapolite & $\mathrm{S}$ \\
\hline Topaz & $\mathrm{P}$ & Pyroxenoids & S & Epidote & $\mathrm{P}$ \\
\hline Beryl & $\mathrm{P}$ & Cassiterite & $\mathbf{P}$ & Barite & $\mathrm{P}$ \\
\hline Tourmaline & $\mathrm{P}$ & Chrysoberyl & $\mathrm{S}$ & Nepheline & $\mathrm{S}$ \\
\hline \multirow[t]{8}{*}{ Fluorite } & $\mathrm{P}$ & Corundum & $\mathrm{S}$ & Amphiboles & $\mathrm{S}$ \\
\hline & & Garnets & $\mathrm{S}$ & Scheelite & $\mathrm{S}$ \\
\hline & & Kyanite & $\mathrm{S}$ & Olivine & $\mathrm{S}$ \\
\hline & & Albite & $\mathrm{S}$ & Chondrodite & $\mathrm{S}$ \\
\hline & & & & Vesuvianite & $\mathrm{S}$ \\
\hline & & & & Zeolites & $\mathrm{S}$ \\
\hline & & & & Zircon & $\mathrm{S}$ \\
\hline & & & & Monazite & $\mathrm{S}$ \\
\hline
\end{tabular}




\section{Inclusion hosts}

Quartz was selected as the study subject, because it is the predominant host for fluid inclusions in metamorphic and magmatic Proterozoic and Archaean rocks in Finland (Table 1). Other minerals, with the exception of carbonates, which commonly include primary and secondary fluid inclusions, are only accessory phases in common rock types, or then they are of much younger geological age, as are the Cretaceous calcite crystals with large primary fluid inclusions found in the caves of the Korsnäs mine in western Finland (Rehtijärvi and Kinnunen 1979).

\section{Material}

The quartz specimens for modal analysis were selected from 13 Proterozoic stratabound, metamorphosed sulphide ore deposits, hydrothermal mineralizations and dimension stone and industrial mineral quarries that have supplied gem-quality smoky quartz in Finland (Table 2). Some of these localities had been studied microthermometrically for their fluid inclusions during explorational reconnaissance (references in Table 2). The locations of the sampling sites are shown in Fig. 1.

\section{Methods}

\section{Linear measurement procedure}

Doubly-polished thick sections, specifically prepared for fluid inclusion studies, and loose grain mounts (Kinnunen 1986) were used as specimens. Modal analysis was performed with randomly selected measuring lines as units. The intercept lengths of the fluid inclusions were measured along each line with a Leitz screw micrometer eyepiece (magnification 16x).

To eliminate the depth effect, the microscope objective used should have a high numerical aperture. The depth of field decreases below 1

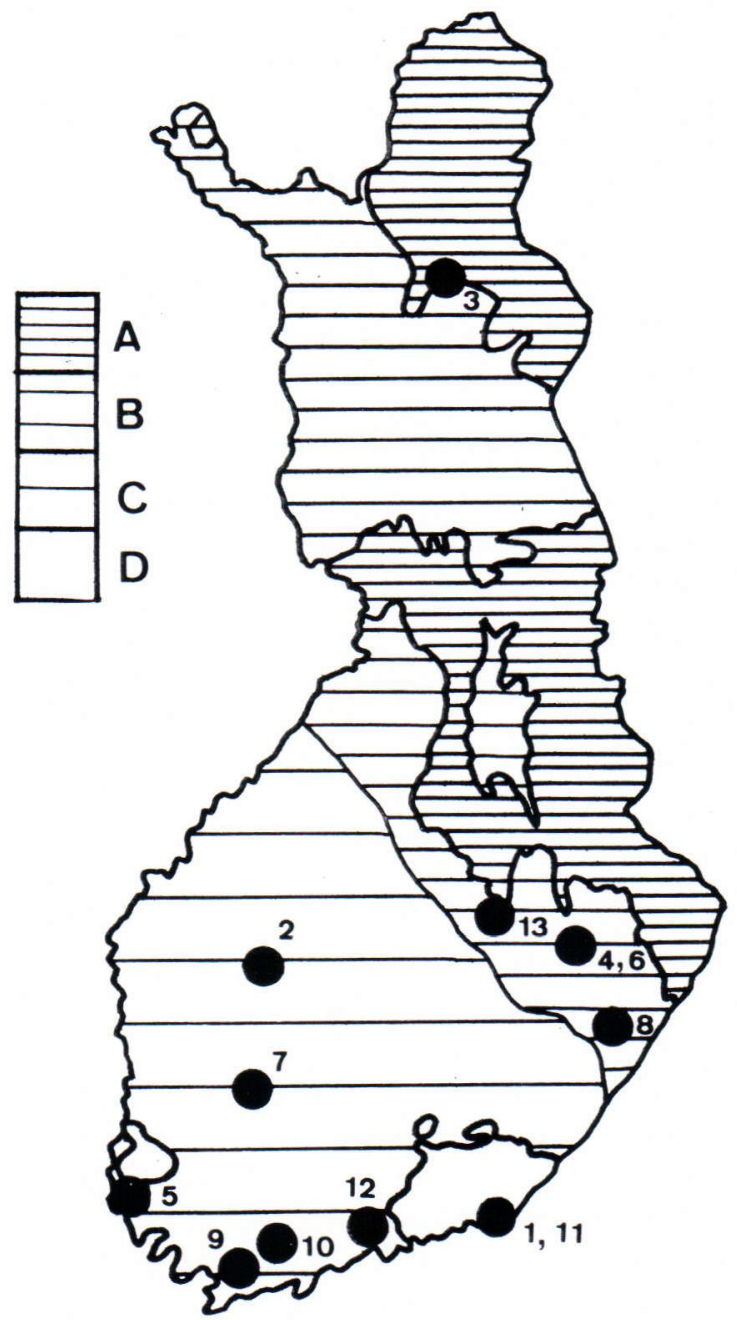

Figure 1. Localities of the fluid inclusion samples listed in Table 2. The generalized geological map of Finland is simplified from Simonen (1980) and Gaál (1986). The numbers refer to the localities in Table 2. Map symbols: $A=$ Archaean terrain; B = Early Proterozoic Karelidic domain; C = Early Proterozoic Svecofennidic domain; D = Early/Middle Proterozoic rapakivi granites.

micrometer if the numerical aperture exceeds 0.6 (Fig. 2 in Hinkelmann 1989). In this study a Leitz NPL 40x fluorite-type plan-achromat with a numerical aperture of 0.70 was used, and thus the depth of field was reduced to 0.8 micrometers. Therefore the inclusions at different sample levels did not hamper the measuring procedure. 
Note that the theoretical lateral resolution of the 0.70 numerical aperture is only 0.5 microns for green light. This determines the minimum diameter of the inclusion cavities that can be studied with an optical microscope.

The length of each measuring line was 94 microns with the optical system constructed. Approximately 120 measuring lines were studied on each specimen. The volume percentage of fluid inclusions was calculated by dividing the sum of the intercept lengths of the inclusions by the total length of the measuring lines and by multiplying the quotient by a hundred. According to the geometrical relations outlined by Chayes (1956) and Jones (1987), this one-dimensional figure equals the three-dimensional volume percentage content.

\section{Classification of inclusions}

The fluid inclusions in the samples studied were grouped into primary, pseudosecondary and secondary types according to the criteria listed by Roedder (1984). The fluid inclusion fillings were classified into five main types (Table 2 ) with a Chaix-Meca crushing stage using appropriate reagents for the detection of carbon dioxide and organic gases under pressure following the procedures in Roedder (1970). Additional tests were performed with a Chaix-Meca heating/freezing stage and with drops of micro-cooling liquids to confirm some of the identifications. To eliminate the effects of the necking-down phenomena typical of some secondary fluid inclusion planes in quartz, only the main inclusion type in each inclusion plane was noted.

An attempt at a more detailed classification of the S4 inclusions was tried using a crushing stage and microthermometrical data but with equivocal results. Most of the inclusions turned out to be complicated multicomponent systems mainly composed of carbon dioxide plus several minor components, as seen from the common stepwise dissolution of the liberated gas bubbles. Pure end members were rare, and the gaseous-type inclu- sions encountered in this study were classified exclusively in the S4 type.

\section{Fluid inclusion data}

The volume contents of fluid inclusions expressed in percentages, the inclusion assemblages, the mean and maximum intercept lengths and the corresponding filling types are given in Table 2 .

\section{Volume contents}

The highest volume contents of the fluid inclusions were determined from large quartz crystals. These crystals contained comparatively large primary inclusions, which increased the volume content. Secondary inclusions were common in their fractured base. Almost all large quartz crystals, studied in other connections (data not given here), from chambers and vugs in complex pegmatites, open veins and miarolitic cavities in rapakivi granites revealed high total inclusion contents.

The smoky quartz crystals from the Kaatiala rare element pegmatite quarry in Kuortane and the Pyterlahti rapakivi granite quarry in Virolahti were selected as typical examples of this material (Figs. 1 and 2, Table 2). The morion-type smoky quartz crystals from these localities have been widely used as cabochon material, but the final polishing of many crystals has failed owing to the presence of exposed inclusion cavities and the deposition of polishing powder in these cavities. The present inclusion study suggests that the terminated ends of morion crystals should preferably be used as cutting material, because the fluid inclusion contents are lower at the end of the quartz crystals than at their fractured base.

The second highest fluid inclusion contents were observed in vein quartzes (Table 2). These quartzes are characterized by secondary inclusions of several (from 2 to 4) types and generations. Although the typical milky and grey colour is caused by the scattering of light from clouds of secondary fluid inclusions (Frondel 1962), the 
Table 2. Fluid inclusion volume percentage, sizes and types in the quartz of some Finnish rocks and ore deposits. See Fig. 1 for locations.

\begin{tabular}{|c|c|c|c|c|c|c|c|}
\hline \multirow{3}{*}{$\begin{array}{l}\text { No.in } \\
\text { map }\end{array}$} & \multirow[t]{3}{*}{ Name and type of deposit } & \multirow{3}{*}{$\begin{array}{l}\text { Specimen } \\
\text { type }\end{array}$} & \multicolumn{5}{|c|}{ Fluid inclusion data } \\
\hline & & & \multirow[t]{2}{*}{ assemblages } & \multicolumn{2}{|c|}{$\begin{array}{l}\text { intercept lengths } \\
\text { in microns }\end{array}$} & \multirow[t]{2}{*}{$\begin{array}{c}\text { volume } \\
\text { percentage }\end{array}$} & \multirow[t]{2}{*}{$\begin{array}{l}\text { reference } \\
\text { to inclusions }\end{array}$} \\
\hline & & & & mean & $\max$ & & \\
\hline \multirow{3}{*}{$\begin{array}{l}1 . \\
2 . \\
3 .\end{array}$} & Pyterlahti, rapakivi granite quarry & miarolitic crystal & $\mathrm{P} 2, \mathrm{PS} 2, \mathrm{~S} 1, \mathrm{~S} 2, \mathrm{~S} 5$ & 5.44 & 58.5 & 1.661 & Kinnunen et al. 1987 \\
\hline & Kaatiala, rare-element pegmatite quarry & chamber crystal & P3, PS3, S1, S3, S5 & 5.83 & 46.8 & 1.070 & Kinnunen $1976 a$ \\
\hline & $\begin{array}{l}\text { Palokiimaselkä, quartz-carbonate vein Au } \\
\text { mineralization }\end{array}$ & vein quartz & $\mathrm{S} 2, \mathrm{~S} 5$ & 3.13 & 7.49 & 0.917 & Kinnunen 1980b \\
\hline \multirow[t]{2}{*}{4.} & Outokumpu Keretti, metamorphosed strata- & & & & & & \\
\hline & bound $\mathrm{Cu}-\mathrm{Zn}$-Co deposit & vein quartz & $\mathrm{S} 2, \mathrm{~S} 4, \mathrm{~S} 5$ & 1.78 & 7.64 & 0.810 & Kinnunen 1981 \\
\hline \multirow{2}{*}{$\begin{array}{l}5 . \\
6 .\end{array}$} & Uhlu, rapakivi granite quarry & rapakivi granite & $\mathrm{S} 2, \mathrm{~S} 4, \mathrm{~S} 5$ & 1.65 & 3.67 & 0.326 & Kinnunen 1976a \\
\hline & $\begin{array}{l}\text { Outokumpu Keretti, metamorphosed strata- } \\
\text { bound } \mathrm{Cu}-\mathrm{Zn} \text {-Co deposit }\end{array}$ & massive ore & S2, S4, S5 & 1.11 & 3.12 & 0.323 & Kinnunen 1981 \\
\hline \multirow{3}{*}{$\begin{array}{l}7 . \\
8 .\end{array}$} & Ylöjärvi, tourmaline breccia $\mathrm{Cu}-\mathrm{W}$ deposit & vein quartz & $\mathrm{S} 1, \mathrm{~S} 2, \mathrm{~S} 5$ & 1.06 & 2.34 & 0.236 & Kinnunen 1976b \\
\hline & Hammaslahti, metamorphosed strata-bound & & & & & & \\
\hline & $\mathrm{Cu}-\mathrm{Zn}$ deposit & massive ore & $\mathrm{S} 2, \mathrm{~S} 4, \mathrm{~S} 5$ & 1.12 & 7.80 & 0.155 & Hyvärinen et al. 1977 \\
\hline \multirow[t]{2}{*}{9.} & Orijärvi, metamorphosed strata-bound & & & & & & \\
\hline & $\mathrm{Zn}-\mathrm{Cu}$ deposit & massive ore & S4, S5 & 0.92 & 3.12 & 0.108 & Kinnunen 1976a \\
\hline 10. & Ojamo, metamorphosed limestone quarry & pegmatite vein & $\mathrm{S} 2, \mathrm{~S} 4, \mathrm{~S} 5$ & 1.25 & 7.49 & 0.087 & - \\
\hline 11. & Pyterlahti, rapakivi granite quarry & pyterlite & $\mathrm{S} 2, \mathrm{~S} 4, \mathrm{~S} 5$ & 0.59 & 0.94 & 0.056 & Kinnunen et al. 1987 \\
\hline 12. & Lakeakallio, uraniferous migmatite & migmatite & $\mathrm{S} 1, \mathrm{~S} 2, \mathrm{~S} 4, \mathrm{~S} 5$ & 0.19 & 0.62 & 0.032 & Appelqvist and Kinnunen 1977 \\
\hline 13. & Nilsiä, quartzite quarry & quartzite & $\mathrm{S} 1, \mathrm{~S} 4, \mathrm{~S} 5$ & 0.70 & 1.33 & 0.028 & - \\
\hline
\end{tabular}

Fluid inclusion assemblages:

$\mathrm{P}=$ primary fluid inclusion; $\mathrm{PS}=$ pseudosecondary; $\mathrm{S}=$ secondary

1 = aqueous type: water solution plus vapour bubble

2 = 'brine' type: water solution plus solid crystal(s) plus vapour bubble

3 = mixed type: water solution plus liquid carbon dioxide plus vapour bubble plus/minus solid crystal(s)

4 = gaseous type: mainly carbon dioxide liquid plus vapour

5 = aqueous low-temperature type: monophase liquid water 
contents are not as high as those measured from euhedral crystals. This is attributed to the very small size of the secondary inclusions in vein quartz (Table 2).

The quartzes from rocks and massive ore types showed only secondary fluid inclusions and therefore lower fluid inclusion contents (Fig. 2, Table 2). Only exceptionally did these quartzes contain comparatively large »isolated» secondary inclusions. However, even these inclusions were found to lie along surfaces when examined on a universal stage. They usually contained only very small secondary inclusions on planes of plastic and/or brittle deformation as described by Wilkins and Barkas (1978). The quartz samples from metamorphosed sulphide ores usually had somewhat higher inclusion contents than those from ordinary barren rocks. The samples from in or near hydrothermal mineralizations were especially rich in secondary inclusions (No. 3 in Table 2).

\section{Inclusion assemblages}

The various filling types of secondary fluid inclusions revealed some interesting petrographical characteristics. S5 inclusions were preferably located on sharp, healed microfractures usually cutting several mineral grains. S1 and, rarely, S4 inclusions (eg. No. 13 in Table 2) sometimes lay along diffuse planar planes of plastic deformation character and totally inside (!) the individual quartz grains. Unfortunately, the minute size of these S1 inclusions prevented them from being studied in greater detail. This petrographic observation strongly suggests that some of the S1 inclusions may have exsolved from the quartz lattice during plastic deformation (see Wilkins and Barkas 1978). Usually, however, the S1 and especially the S4 inclusions are situated on ordinary healed fracture planes terminating at the grain boundary or, in some cases, cutting several mineral grains.

The fluid inclusion contents of the rapakivi granite quartz were higher in the Uhlu, Vehmaa rapakivi batholite than in the Pyterlahti, Wiborg rapakivi batholite (Nos. 5 and 11 in Table 2), although the present study contains too few data to allow an areal comparison to be made. Both of these rapakivi granite types contain S2 inclusions, which are the main carriers of chlorides in rapakivi quartz (Haapala and Kinnunen 1979). This fact provides some foundation for the interpretation of the source of salt components in deep saline ground waters (see Hyyppä 1963; Kankainen 1982; Hyyppä 1984; Nurmi et al. 1988) and their relationship, if any, to microcracks (Suominen 1983) in rapakivi granite areas of Finland.

\section{Inclusion sizes}

A positive linear correlation exists between the average intercept lengths and the volume percentage of fluid inclusions in quartz as shown by the statistical parameters derived from the data in Table 2. The correlation coefficient is high, 0.915 , and the correlation obeys the equation

$$
\mathrm{y}=-0.0046+0.26 \mathrm{x}
$$

where $y$ is the volume percentage and $x$ the arithmetical mean of the intercept length expressed in microns. The correlation can be explained by the geometry: the increase in the volume content in relation to the intercept lengths (arbitrary diameter of inclusion cavities) obeys a third order power function. Although the larger inclusions have a marked effect on the arithmetical mean used as an average, this trivial equation offers an easy way of making a preliminary assessment of the inclusion volume contents in ordinary specimens.

The size of the fluid inclusions in the quartz of Finnish metamorphic rocks is exceedingly small, the intercept lengths usually being less than a few microns. Moreover, in all the specimens studied, only secondary inclusions were observed. This makes it very difficult to study the inclusions under the optical microscope, especially on a heating/freezing stage. The minimum sizes indi- 


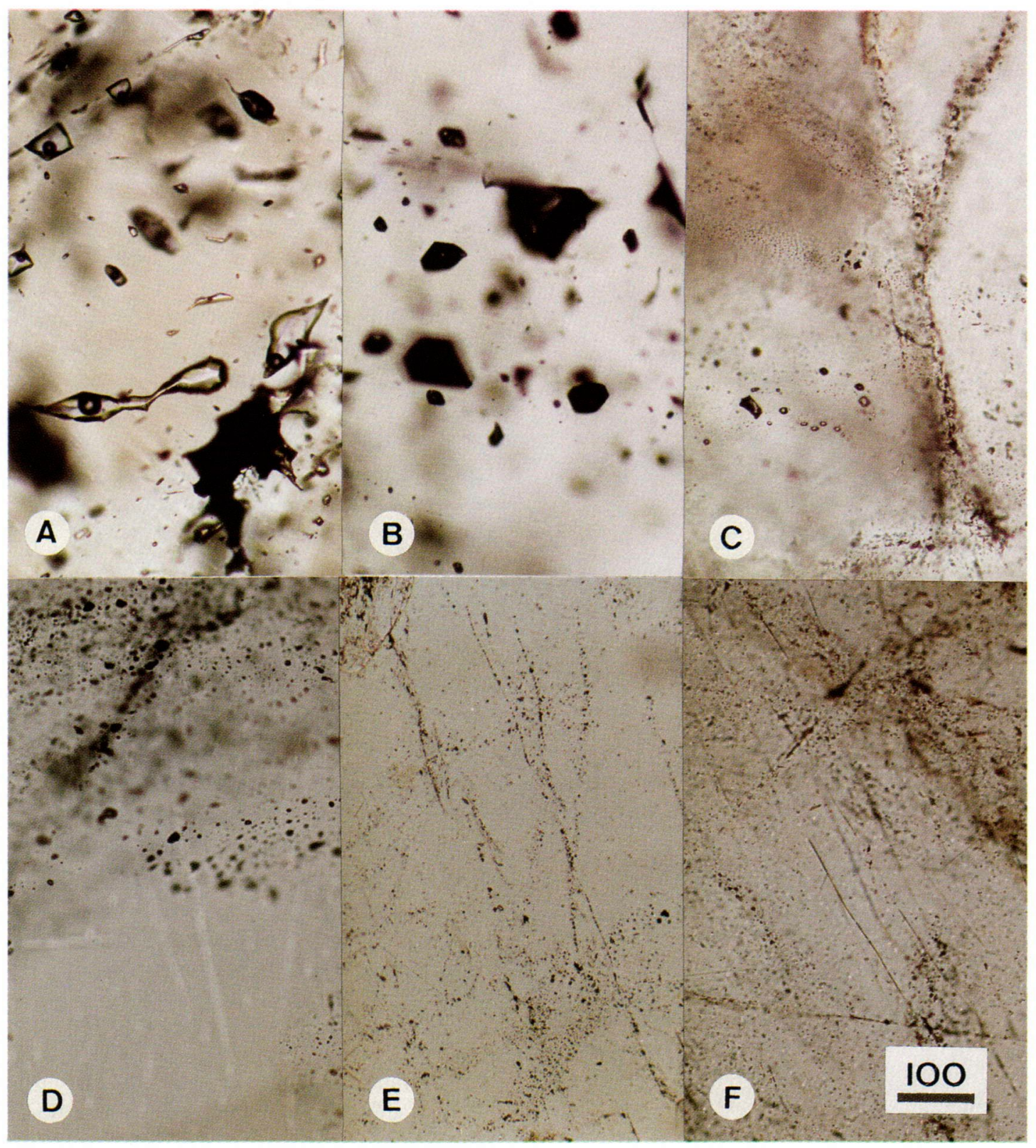

Figure 2. Photomicrographs showing typical fluid inclusion assemblages with different fluid inclusion volume contents in quartz crystals and in rock-forming quartz grains. Note the large size of inclusion cavities in quartz crystals (A and B) compared with the rock-forming quartz (C-F). A. Smoky quartz crystal from Pyterlahti granite quarry with S1, S2 and S5 inclusions, fluid inclusion volume percentage 1.661, specimen GSF 27395. B. Smoky quartz crystal from Kaatiala pegmatite quarry with PS3 and S3 inclusions, fluid inclusion volume percentage 1.070, specimen GSF 23154. C. Quartz from massive sulphide ore, Outokumpu Keretti mine, with S2 and S4 inclusions, fluid inclusion volume percentage 0.323, specimen GSF 24147. D. Quartz from a massive sulphide ore, Orijärvi mine, with S4 inclusions, fluid inclusion volume percentage 0.108, specimen GSF 21487. E. Rock-forming quartz from pyterlitic rapakivi granite, dimension-stone quarry in Pyterlahti, with S2, S4 and S5 inclusions, fluid inclusion volume percentage 0.056 , specimen GSF 26715 . F. Rock-forming quartz from uraniferous migmatite in the Lakeakallio mineralization with S1, S4 and S5 inclusions, fluid inclusion volume percentage 0.032, specimen GSF 21627. Magnification is the same in each photomicrograph (A-F). Scale bar in microns. 
cate merely the resolution of the optical system used.

Smaller inclusion cavities had been found during some earlier scanning electron microscope examinations on the fractured and polished surfaces of quartzes from the Kaatiala pegmatite quarry and the Keretti mine (University of Helsinki, Geology Department in 1974; Helsinki University of Technology, Electron Microscopy Laboratory in 1979). The specimens contained very few inclusions of submicroscopic size and the ratio of the inclusion sizes to the abundances remained visually constant at magnifications up to $10,000 x$. Because these submicroscopic inclusions have only a neglible effect on the total volumes measured, they were omitted here. Furthermore, fluid inclusions as such are defined as cavities in minerals $1.0-100.0$ microns in diameter (Bates and Jackson 1987); in some Finnish rocks (Nos. 11 and 12 in Table 2) the intercept lengths of even the largest measured - and found - inclusions were below this 1 micron limit.

\section{Discussion and conclusions}

Fluid inclusion contents were highest in individual euhedral crystals, as the comparatively few large primary inclusions increase the volume contents (see Fig. 2). In metamorphic quartz samples the inclusion contents are low owing to the predominance of very small secondary fluid inclusions.

\section{Size problem}

The exceedingly small size of the fluid inclusions in metamorphic rock-forming quartzes, which was known but had not been accurately measured before, was an unexpected result. Most of the S1 and S4 types and some of the S2 and S5 types are near or below the limits of resolution of the optical microscope. Larger primary inclusions are common only in euhedral quartz crystals. This also applies to other mineral species studied (Table 1) from crystalline bedrock. The scarcity of primary, genetically important inclusions together with the exceedingly small size of the common secondary inclusions makes it difficult to apply instrumental fluid inclusion studies to Finnish rocks at present.

\section{Relation to rock types}

The S5 type, which was detected in all samples, is the only universal fluid inclusion type in the samples studied. These monophase water inclusions were formed at very low temperature in microfractures (see Roedder 1984; Arnold 1986). The S4 inclusions are typical of metamorphic terrains (Schreurs 1984; Crawford and Hollister 1986; Kerkhof 1988; Newton 1989) but they have also been found in the quartz of rapakivi granites. The ores and mineralizations studied typically contained S2, PS2 and P2 inclusions of high salinity and density. According to the present data, the three-member assemblage - S1/S2, S4, S5 - is typical of Proterozoic metaquartz. In addition to these, Poutiainen (1989) has identified gaseous secondary fluid inclusions with methane plus/minus nitrogen filling from some metamorphic quartz veins in the Joroinen Sulkava area in Central Finland. The S3 inclusions, and especially the P3 and PS3 inclusions, seem to characterize the quartz in complex and simple pegmatites (see Kinnunen 1976a).

\section{Relation to saline ground waters}

It has been suggested that the salt components in saline and brine-type ground waters at deeper levels in old shield areas originate not only from ordinary fluid-rock interactions through hydrolysis of plagioclase and biotite (see Peters 1986; Nurmi et al. 1988) but also from destroyed fluid inclusions in granitoids (Lindblom 1984). However, the low contents of fluid inclusions determined from the metamorphic specimens and the rapakivi granite quartz in this study do not support this hypothesis. Young, unhealed microfrac- 
tures cutting through inclusion cavities and releasing the inclusion fluids into the surrounding ground water are only two-dimensional planar surfaces and evidently do not destroy all the inclusions in a quartz grain. Note that unhealed microfractures, as such, were rare in the inspected specimens. Besides, only in quartz veins and in monomineralic quartzite (Nos. 3, 4, 7, 13 in Table 1) do the inclusion contents represent the total content in specified rocks. In other cases, excluding the quartz crystals, the contents determined for quartz must be corrected with the modal content of quartz in the rock type.

Other minerals that could host considerable amounts of fluid inclusions are rare in granitoids. Moreover, only part of the fluid inclusion assemblage is composed of S2 and/or S1 and S3 types (see Table 2), which are the main carriers of the salt components. In contrast to the models discussed, it is here proposed that some of the unhealed low-temperature type S5 inclusions in the quartz of granitoids (Table 2) may, in fact, represent saline ground water in crystalline bedrock. According to the most recent studies of Arnold (1986), the metastable, monophase aqueous fluid inclusions, here classified as the S5 type, were trapped under PT conditions very close to room temperature.

\section{Use in prospecting}

The fluid inclusion volume contents also have interesting implications for prospecting. Mesozoic and Cenozoic porphyry copper deposits and many hydrothermal deposits of various geological ages are characterized by high visual abundances of fluid inclusions in quartz (Nash 1976). This may justify the explorational use of decrepitation (Sitaramayya 1982), which basically rests on the high - albeit not accurately determined - abundances and large size of fluid inclusions as discussed by Yermakov (1965) and Hladky and Wilkins (1987). For some ore types the high contents of fluid inclusions may, therefore, correlate with the ore potential of the host rocks. However, the high contents of secondary fluid inclusions do not necessarily indicate large volumes of fluid flow (in flow pores); rather, they refer to the high degree of microfracturing (as diffusional pores) which favoured the trapping of fluids (see Norton and Knapp 1977).

\section{Source of fluid types}

The contents of the $\mathrm{S} 1$ inclusions in metamorphic quartz may have unexpected genetic implications for metamorphic petrology through the hydrolythic weakening of quartz, as experimentally shown by Blacic (1975). Roedder (1981) has thus emphasized the problematic nature of secondary fluid inclusions in metaquartz. It has repeatedly been proposed that many aqueous secondary fluid inclusions, related to ductile deformation and common in metamorphic quartz, may have been formed by exsolution in hydrogen diffusion (Wilkins and Barkas 1978; Eadington and Wilkins 1980; Spear and Selverstone 1983).

In laboratory experiments, submicroscopic aqueous fluid inclusions have precipitated from hydrogen defects during heat treatment of amethyst and synthetic quartz (McLaren et al. 1983; Cordier et al. 1988). The contents of fluid inclusions in typical magmatic and metamorphic rock samples (Nos. 9-13 in Table 2) are of the right magnitude provided the solubility of $\mathrm{H}_{2} \mathrm{O}$ in the quartz lattice was about $300 \mathrm{ppm}$ at $3 \mathrm{~kb}$ as given by Spear and Selverstone (1983). The petrographic observations of diffuse planes of S1 inclusions restricting their occurrence totally inside the metaquartz grains (e.g. No. 13 in Table 2) seem to support this hypothesis. Microscopically very similar inclusions have been seen in the cloudy areas formed in the laboratory heat treatment of Finnish amethyst crystals and described by Kinnunen (1980a) from the old Stansvik iron mine in Helsinki. If this hypothesis is valid, these aqueous exsolution fluid inclusions in metamorphic quartz reflect the primary composition of the quartz itself and its readjustment to changing PT conditions - rather than the composi- 
tion of the discrete metamorphogenic intergranular fluid, as usually interpreted in recent fluid inclusion studies (see Kreulen 1987).

Perhaps both types are present in Finnish Proterozoic metaquartz. The S4 inclusions may be interpreted as intergranular metamorphogenic fluids (see Touret 1982). Some of the S1 inclusions bear a resemblance to the exsolutional model. Usually, however, S1 and S2 can be interpreted as ordinary intergranular metamorphogenic and/or hydrothermal fluids. In some microcracks S5 may be very recent and connected with saline groundwaters (see Arnold 1986). In theory, the secondary inclusions in metaquartz could have trapped many types of the fluid generation present in the crust at various times, provided that brittle fracturing suitable for the formation of inclusion cavities had occurred. The problems mainly focus on the difficulty of determining the relative ages of the many types and generations of the secondary fluid inclusions present in metaquartz.

\section{Origin of inclusion cavities}

The data on the fluid inclusions in Finnish quartz samples show that the contents of the fluid inclusions in rock-forming quartz differ from those in quartz crystals in origin. In the rockforming quartz the contents of inclusions mainly indicate the degree of brittle fracturing of the quartz and perhaps only to a limited extent the degree of exsolution during ductile deformation related to recovery as suggested by White (1973). According to the laboratory simulations performed by Shelton and Orville (1980), the synthetic secondary fluid inclusions in quartz are localized along former fracture-surface step lineations.

In quartz crystals the contents of fluid inclusions are mainly due to imperfections in the crystal growth mechanism, eventually leading to the formation of primary inclusions, but also to the degree of brittle fracturing at the base of the crystals, which causes the formation of secondary in- clusions. Mosaic or lineage structures in crystal growth associated with a high dislocation density are considered to be the main reason for the formation of primary fluid inclusions (see Chapter 2 in Roedder 1984 for detailed references). The contents of primary fluid inclusions in quartz crystals can therefore be considered as a function of the crystal growth mechanism involved and imperfections induced by its microenvironment (solid particles on growing crystal faces, immiscibility, fluctuating PTX environment, etc.).

\section{Applications}

The described linear measurement procedure modified from Rosiwal's method and applied to the modal analysis of fluid inclusion content gives reasonably accurate results, but it is too timeconsuming to be recommended as a routine procedure. It may find use in studies of a few selected samples whose inclusion contents it is important to know. An example is the need for accurate chemical data on total fluid inclusion composition. With its very small sample size requirements (about $0.2 \mathrm{~g}$ ), neutron activation analysis could be a possible method if combined with determined fluid inclusion contents.

The observed correlation between fluid inclusion mean size and the volume percentage may be used as a preliminary estimate of the volume content for routine studies. It can be determined relatively rapidly by making a few measurements with a screw micrometer eyepiece from loose grain mounts (Kinnunen 1986) or from doublypolished thick sections.

Acknowledgements. I thank my referees, Professor I. Haapala and Dr. M. Vaasjoki, and also M. Poutiainen, for their useful comments. Mr. B. Saltikoff, H. Appelqvist, M. Tontti and $\mathrm{R}$. Saikkonen reviewed the paper critically and made many constructive comments. I am also indebted to J. Pääkkönen for preparing numerous excellent doubly-polished thick and thin sections essential for inclusion studies. Mrs. Gillian Häkli corrected the English of the manuscript. I am grateful to all these persons for their help. 


\section{References}

Appelqvist, H. \& Kinnunen, K.A., 1977. Raportti geologisen tutkimuslaitoksen uraanitutkimuksista AskolanPorvoon alueella 1976-1977. Unpubl. rep., Geol. Surv. Finland, Central archive, M19/3022/77/1/10, 12 p.

Arnold, M., 1986. So-called metastable monophase aqueous fluid inclusions at room temperature. C.R. Acad. Sci. Paris 303, Ser. II, No. 6, 459-461. (In French. Translation in Roedder, E. and Kozlowski, A. (eds.), Fluid Inclusion Research, Proceedings of COFFI 19, 499-501, University of Michigan Press.)

Bates, R.L. \& Jackson, J.A., eds., 1987. Glossary of Geology. Third edition. American Geological Institute, Alexandria, Virginia, $788 \mathrm{p}$.

Blacic, J.D., 1975. Plastic-deformation mechanism in quartz: The effect of water. Tectonophysics 27, 271-294.

Chayes, F., 1956. Petrographic Modal Analysis. Wiley, New York, $113 \mathrm{p}$.

Cordier, P., Boulogne, B. \& Doukhan, J.-C., 1988. Water precipitation and diffusion in wet quartz and wet berlinite $\mathrm{AlPO}_{4}$. Bull. Mineral. 111, 113-137.

Crawford, M.L. \& Hollister, L.S., 1986. Metamorphic fluids: the evidence from fluid inclusions. In Walther, J.V. and Wood, B.J. (eds.) Fluid-Rock Interactions during Metamorphism. Springer, New York, pp. 1-35.

Eadington, P.J. \& Wilkins, R.W.T., 1980. The origin, interpretation, and chemical analysis of fluid inclusions in minerals. Technical Communication 69, Institute of Earth Resources, CSIRO, $30 \mathrm{p}$.

Frondel, C., 1962. Silica Minerals. The System of Mineralogy. Vol. III. Seventh edition. Wiley, New York, 334 p.

Gaál, G., 1986. 2200 million years of crustal evolution: The Baltic shield. Bull. Geol. Soc. Finland 58, Part 1, $149-168$.

Haapala, I. \& Kinnunen, K.A., 1979. Fluid inclusions in cassiterite and beryl in greisen veins in the Eurajoki Stock, southwestern Finland. Econ .Geol. 74, 1231-1238.

Hinkelmann, H., 1989. Light microscopes for cell and molecular biology. Internat. Biotechnology Lab. 7, $20-23$.

Hladky, G. \& Wilkins, R.W.T., 1987. A new approach to fluid inclusion decrepitometry - practice. Chem. Geol. $61,37-45$.

Holloway, J.R., 1981. Composition and volumes of supercritical fluids in the Earth's crust. In Hollister, L.S. and Crawford, M.L. (eds.) Fluid Inclusions: Applications to Petrology. Mineralogical Association of Canada, Short Course Handbook, Vol. 6, pp. 13-38.

Hyvärinen, L.; Kinnunen, K.A. \& Mäkelä, M., 1977. The geochemistry, fluid inclusions, sulfur isotopes and origin of the Hammaslahti copper ore deposit, Finland. Geol. Surv. Finland, Bulletin 293, 23 p.

Hyуррӓ, J., 1963. Eurassa kallioperään poratun syväkaivon suolaisen veden koostumuksesta. Geologi 6, 61-63.

-, 1984. Chemical composition of groundwater in Finnish bedrock. Geol. Surv. Finland, Nuclear Waste Disposal Research, Report YJT-84-10, 69 p.

—, 1986. Kallioperän pohjaveden kemiallinen koostumus Suomessa ja muilla prekambrisilla kilpialueilla. Geol. Surv. Finland, Nuclear Waste Disposal Research, Report YJTÜ30, $108 \mathrm{p}$.

Jones, M.P., 1987. Applied Mineralogy. A Quantitative Approach. Graham \& Trotman, London, 259 p.

Kankainen, T., 1982. Loviisan Hästholmenin tutkimusreikien Y1, Y2 ja Y5 pohjavesinäytteiden iänmääritykset. Summary: Dating of ground water from the boreholes Y1, Y2 and Y5 in Loviisa, Hästholmen, Finland. Geol. Surv. Finland, Nuclear Waste Disposal Research, Report YJT-82-19, 30 p.

Kerkhof, A.M. van den, 1988. The system $\mathrm{CO}_{2}-\mathrm{CH}_{4}-\mathrm{N}_{2}$ in fluid inclusions: Theoretical modelling and geological applications. Free University Press, Amsterdam, 206 p.

Kinnunen, K.A., 1976a. Fluidisulkeumatutkimuksia eräistä Suomen malmiesiintymistä. (Fluid inclusion studies on some Finnish ore deposits.) Unpublished Phil. lic. thesis, University of Helsinki, Dep. of Geology and Mineralogy, $78 \mathrm{p}$.

-, 1976b. Kvartsin sulkeumat Porvoon turmaliinibreksialohkareessa ja eräissä sen mahdollisista alkuperäkivilajeissa. Unpubl. rep., Geol. Surv. Finland, Central archive, M19/3021/76/1/10, 3 p.

—, 1980a. Stansvikin ametisteista. Summary: Hematite spherules in amethyst from Stansvik, southern Finland. Geologi 32, 49-52.

—, 1980b. Fluidisulkeuma-tutkimus Sodankylän Palokiimaselän kultaesiintymän kvartsijuonista. Unpubl. rep., Geol. Surv. Finland, Central archive, M19/3742/80/1/10, 9 p.

-, 1981. Outokumpu-tyyppisten malmipuhkeamien ja lohkareiden vertailu fluidisulkeumistojen avulla. Summary: Comparison of fluid inclusion assemblages of Outokumpu-type ore outcrops and boulders in eastern Finland. Geol. Surv. Finland, Rep. Investigation 51, 40 p.

-, 1986. Yksinkertainen menetelmä fluidisulkeumien etsintään. Summary: A simple method for pilot fluid inclusion studies. Geologi 38, 133-134.

-, Lindqvist, K. \& Lahtinen, R., 1987. Fluid history from crystal cavities in rapakivi, Pyterlahti, southeastern Finland. Bull. Geol. Soc. Finland 59, Part 1, 35-44.

Kreulen, $R$., 1987. Thermodynamic calculations of the C-O$\mathrm{H}$ system applied to fluid inclusions: Are fluid inclusions unbiassed samples of ancient fluids? Chemical Geology $61(1 / 4), 59-64$.

Lindblom, S., 1984. Fluid inclusion studies in the Stripa granite. Hydrological and hydrogeochemical investigations in boreholes. Stripa Project 84-07, $42 \mathrm{p}$.

McLaren, A.C.; Cook, R.F.; Hyde, S.T. \& Tobin, R.C., 
1983. The mechanisms of the formation and growth of water bubbles and associated dislocation loops in synthetic quartz. Phys. Chem. Minerals 9, 79-94.

Nash, J.T., 1976. Fluid-inclusion petrology — data from porphyry copper deposits and applications to exploration. U.S. Geol. Surv. Prof. Paper 907-D, 16 p.

Newton, R.C., 1989. Metamorphic fluids in the deep crust. Ann. Rev. Earth Planet. Sci. 17, 385-412.

Norton, D. \& Knapp, R., 1977. Transport phenomena in hydrothermal systems: The nature of porosity. Amer. Jour. Sci. 277, 913-936.

Nurmi, P.A.; Kukkonen, I.T. \& Lahermo, P. W., 1988. Geochemistry and origin of saline groundwaters in the Fennoscandian Shield. Applied Geochemistry 3 (2), 185-203.

Peters, T., 1986. Structurally incorporated and water extractable chlorine in the Boettstein granite. Contrib. Mineral. Petrol. 94, 272-273.

Poutiainen, M., 1989. Metamorfisen fluidifaasin kehitys Joroisten - Sulkavan alueella. Unpublished Phil. lic. thesis, University of Helsinki, Dep. of Geology and Mineralogy, $72 \mathrm{p}$.

Rehtijärvi, P. \& Kinnunen, K.A., 1979. Fluid and mineral inclusions and inclusion zones of cave calcite from Korsnäs mine, western Finland. Bull. Geol. Soc. Finland 51, $75-79$.

Roedder, E., 1970. Application of an improved crushing microscope stage to studies of the gases in fluid inclusions. Schweiz. Mineral. Petrogr. Mitt. 50, 41-58.

- , 1981. Problems in the use of fluid inclusions to investigate fluid-rock interactions in igneous and metamorphic processes. Fortschr. Miner. 59, 267-302.

-, 1984. Fluid Inclusions. Reviews in Mineralogy, 12. Miner. Soc. America, Washington, D.C., 644 p.

Saikkonen, R., 1981. Kvartsi teollisuusmineraalina. Symposium on Industrial Minerals 6.11.1981. Vuorimiesyhdistys, Espoo, p. 6.

Schreurs, J., 1984. The amphibolite-granulite facies transition in West Uusimaa, S.W. Finland. A fluid inclusion study. Jour. Metamorphic Geol. 2, 327-341.

Shatagin, N.N., 1981. Rapid method of evaluation of amount of inclusions in minerals. Zapiski Vses. Mineral. Obshch. 110, 112-118. (In Russian. Translation in Roedder, E. and Kozlowski, A. (eds.), Fluid Inclusion Research, Proceedings of COFFI 14, 282-286, University of Michigan Press.)

Shelton, K.L. \& Orville, P.M., 1980. Formation of synthetic fluid inclusions in natural quartz. Amer. Miner. 65, $1233-1236$.
Simonen, A., 1980. The Precambrian in Finland. Geol. Surv. Finland, Bulletin 304, 58 p.

Sitaramayya, S., 1982. Decrepitometric mapping - A useful prospecting method. In Sahu, K.C. and Panchapakesan, V. (eds.) National Workshop on Fluid Inclusion Studies, Proceedings. Indian Institute of Technology, Bombay, pp. 99-104.

Spear, F.S. \& Selverstone, J., 1983. Water exsolution from quartz: Implications for the generation of retrograde metamorphic fluids. Geology 11, 82-85.

Suominen, V., 1983. Loviisan Hästholmenin geologinen rakenne: yhteenveto kallionäytekairauksien Y1-Y11 kallioperägeologisista tutkimuksista. Geol. Surv. Finland, Nuclear Waste Disposal Research, Report YJT-83-03, 27 p. and 33 appendixes.

Touret, J.L.R., 1981. Fluid inclusions in high grade metamorphic rocks. In Hollister, L.S. and Crawford, M.L. (eds.), Fluid Inclusions: Applications to Petrology. Mineralogical Association of Canada, Short Course Handbook, vol. 6, pp. 182-208.

Ventslovayte, Ye.I. \& Valyashko, L.M., 1985. Water content of gas-liquid inclusions in quartz and depth of its formation. Abst. Seventh All-Union Conf. on Thermobarometry \& Geochemistry of Ore Forming Fluids, L'vov, USSR, Sept. 1985, Vol. 2, 232-233. (In Russian. Translation in Roedder, E. and Kozlowski, A. (eds.), Fluid Inclusion Research, Proceedings of COFFI 19, 458, University of Michigan Press.)

White, S., 1973. The dislocation structures responsible for the optical effects in some naturally-deformed quartzes. Jour. Materials Sci. 8, 490-499.

Wilkins, R.W.T. \& Barkas, J.P., 1978. Fluid inclusions, deformation and recrystallization in granite tectonites. Contrib. Mineral. Petrol. 65, 293-299.

Yermakov, N.P., 1965. Studies of mineral-forming solutions. In Roedder, E. (ed.), Research on the Nature of Mineralforming Solutions. Pergamon Press, Oxford, pp. 3-348.

—, \& Myaz', N.I., 1965. Influence of liquid and gaseous inclusions on magnitudes of losses on ignition of minerals. In Roedder, E. (ed.), Research on the Nature of Mineralforming Solutions. Pergamon Press, Oxford, pp. $526-530$.

Received August 31, 1989

Revision accepted October 12, 1989 